\title{
Penerapan Algoritma Fuzzy C-Means Dipadukan Dengan Model Fuzzy Recency Frequency Monetary (RFM) Untuk Customer Relationship Management (CRM) (Studi Kasus Di Toko Sweet Amirah Medan)
}

\author{
Yohanni Syahra $^{\# 1}$ Yusnidah $^{* 2}$ Beni Andika $^{\# 3}$ \\ ${ }^{\# 1, \# 3}$ Program Studi Sistem Informasi, STMIK Triguna Dharma \\ ${ }^{* 2}$ Akademi Maritim Indonesia (AMI) Medan \\ \#1e-mail: yohannisyahra@gmail.com
}

\begin{abstract}
ABSTRAK
Konsumen merupakan aset yang sangat penting bagi perusahaan retail.Hal ini adalah alasan mengapa perusahaan retail harus merencanakan dan menggunakan strategi yang cukup jelas dalam memperlakukan konsumen.Dengan banyaknya jumlah konsumen yang dimiliki oleh suatu perusahaan retail, maka masalah yang dihadapi adalah bagaimana menentukan konsumen potensial.Dengan menerapkan konsep CRM (Customer Relationship Management), perusahaan dapat melakukan identifikasi konsumen potensial dengan melakukan segmentasi konsumen. Tujuan dari proses segmentasi konsumen adalah untuk mengetahui perilaku konsumen dan menerapkan strategi pemasaran yang tepat sehingga mendatangkan keuntungan bagi pihak perusahaan. Penelitian ini membahas tentang bagaimana proses data mining dari data konsumen di Toko Sweet Amirah, yaitu perusahaan retail yang khusus menjual perlengkapan dan peralatan bayi serta underwear pria dan wanita dewasa dan anak-anak dan berlokasi di Jalan Gedung Arca No. 29 B-C, Medan.Proses Data Mining ini menggunakan data yang berasal dari data penjualan pada Toko Sweet Amirah dan bertujuan untuk mencari konsumen potensial.Model RFM merupakan model segmentasi yang umum digunakan pada perusahaan retail. Selanjutnya melakukan proses clustering menggunakan algoritma Fuzzy C-Means (FCM). Pada FCM jumlah cluster ditentukan. Hasil clustering dari algoritma tersebut digunakan untuk Aplikasi data mining menggunakan MATLAB versi 7.10.0 dan memanfaatkan beberapa toolbox yaitu Fuzzy Logic Toolbox dan Database Toolbox.
\end{abstract}

Kata kunci :Data Mining, Fuzzy C-Means, segmentasi, RFM, CRM

\section{ABSTRACT}

Consumers are a very important asset for the company retail. This is the reason why retailers should plan and use strategies that quite clear in treating consumers. With the large number of consumers that are owned by a retail company, then the problem is how to determine the potential customers. By applying the concept of CRM (Customer Relationship Management), companies can identify potential customers by segmenting consumers. The purpose of the customer segmentation process is to determine consumer behavior and implement appropriate marketing strategies to be profitable for the company. This study discusses how the process of data mining of customer data in Store Sweet Amirah, the retail company that specialized in selling equipment and baby equipment as well as underwear male and female adults and children located in Jalan Gedung Arca No. 29 B-C, Medan. Data Mining is the process of using data derived from sales data on Sweet Shop Amirah and aims to find potential customers. Data Mining process begins with Fuzzy RFM segmentation model to get the consumer class. At FCM specified number of clusters. The clustering results of the algorithm used for data mining applications using MATLAB version 7.10.0 and utilize some of the toolbox that is Fuzzy Logic and Database Toolbox Toolbox. The trials carried out on the sales data in 2014.

Keywords: Data Mining, Fuzzy C-Means, segmentation, RFM, CRM . 


\section{A. PENDAHULUAN}

Toko Sweet Amirah merupakan perusahaan retail yang khusus menjual perlengkapan dan peralatan bayi serta underwear pria dan wanita dewasa dan anak-anak dan berlokasi di Jalan Gedung Arca No. 29 B-C, Medan. Toko Sweet Amirah adalah salah satu perusahaan yang menyadari akan pentingnya hubungan antara pelanggan yang loyal dengan keberhasilan bisnis perusahaan. Sampai tahun 2014, Toko Sweet Amirah memiliki 1.000 pelanggan, 10.000 item barang, dan 100.000 transaksi penjualan. Sejak tahun 2011, Toko Sweet Amirah telah menggunakan sistem informasi berbasis komputer untuk menangani point of sales (POS) dan inventory. Hal ini berdampak pada pertumbuhan jumlah data yang sangat pesat dan menimbulkan tumpukan data yang berjumlah besar dalam basis data. Dengan jumlah data yang sangat besar, Toko Sweet Amirah kesulitan untuk melakukan identifikasi terhadap konsumen terbaiknya. Dengan volume data yang berkembang sangat pesat, baik dari jumlah record dan jumlah field, analisa terhadap data tidak mungkin dilakukan secara manual oleh manusia. Penerapan Data Mining dapat membantu untuk menganalisa data yang diperoleh dari transaksi pada sistem informasi sehingga dapat menggali pola-pola yang dapat dijadikan pengetahuan baru untuk proses identifikasi konsumen di Toko Sweet Amirah.

Data Mining merupakan proses pencarian pola-pola yang menarik dan tersembunyi (hidden pattern) dari suatu kumpulan data yang berukuran besar yang tersimpan dalam suatu basis data, data warehouse, atau tempat penyimpanan data lainnya. Data Mining juga didefinisikan sebagai bagian dari proses penggalian pengetahuan dalam database yang dikenal dengan istilah Knowledge
Discovery in Database (KDD) (Sutrisno, dkk. 2013). Teknik Data Mining yang digunakan untuk mencari segmentasi konsumen adalah menggunakan teknik clustering. Teknik clustering digunakan pada Data Mining untuk mengelompokkan 3 objekobjek yang memiliki kemiripan dalam kelas atau segmen yang sama, sementara objekobjek yang terletak pada kelas yang berbeda menunjukkan karakteristik yang berbeda juga.

\section{B. LANDASAN TEORI}

\section{Knowledge Discoveryin Database (KDD)}

Istilah Knowledge Discoveryin Database (KDD) mulai dikenal pada awal 1990-an. Fayyad pada 1996 menggagas prosess model KDD dan menetapkan langkah untuk proyek Data Mining. Kemudian pada perkembangannya banyak dimodifikasi (Irwan B., 2012).

Knowledge Discoveryin Database (KDD) adalah kegiatan yang meliputi pengumpulan, pemakaian data, historis untuk menemukan keteraturan, pola atau hubungan dalam set data berukuran besar (Mujib R., dkk. 2013).

\section{Data Mining}

Data Mining adalah proses yang menggunakan teknik statistik, perhitungan, kecerdasan buatan dan machine learning untuk mengekstraksi dan mengidentifikasi informasi yang bermanfaat dan pengetahuan yang terkait dari berbagai basis data besar. Data Mining bukanlah suatu bidang yang sama sekali baru. Dalam aplikasinya, Data Mining sebenarnya merupakan bagian dari proses Knowledge Discovery in Database (KDD), bukan sebagai teknologi yang utuh dan berdiri sendiri. Data Mining merupakan salah satu bagian langkah yang penting dalam proses KDD terutama berkaitan dengan ekstraksi 
dan penghitungan pola-pola dari data yang ditelaah (Sutrisno, dkk. 2013).

Istilah Data Mining memiliki hakikat sebagai disiplin ilmu yang tujuan utamanya adalah untuk menemukan, menggali, atau menambang pengetahuan dari data atau informasi yang kita miliki. Data Mining sering juga disebut sebagai Knowledge Discoveryin Database (KDD) (Hemlata S., dkk, 2010).

\section{Clustering}

Clustering adalah studi formal metode dan algoritma untuk partisi atau pengelompokan. Analisis clustering tidak menggunakan pelabelan kategori sebelumnya. Clustering bersifat unsupervised learning atau tidak mempunyai tahap pelatihan data, berbeda dengan klasifikasi. Clustering adalah alat penemuan mengungkapkan hubungan dan struktur di dalam data yang sebelumnya tidak jelas menjadi pengetahuan yang bermanfaat ketika ditemukan (Irwan B., 2012).

Tujuan utama dari metode clustering adalah pengelompokan sejumlah data / obyek ke dalam cluster (group) sehingga dalam setiap cluster akan berisi data yang semirip mungkin. Clustering adalah metode yang berusaha untuk menempatkan obyek yang mirip (jaraknya dekat) dalam satu cluster dan membuat jarak antar cluster sejauh mungkin. Ini berarti obyek dalam satu cluster sangat mirip satu sama lain dan berbeda dengan obyek dalam clustercluster yang lain (Irwan B., 2012).

Clustering digunakan untuk menganalisis pengelompokkan berbeda terhadap data, mirip dengan klasifikasi, namun pengelompokkan belum didefinisikan sebelum dijalankannya tool Data Mining. Clustering membagi item menjadi kelompok-kelompok berdasarkan yang ditemukan tool Data Mining. Prinsip dari clustering adalah memaksimalkan kesamaan antar anggota satu kelas dan meminimumkan kesamaan antar cluster. Clustering dapat dilakukan pada data yang memiliki beberapa atribut yang dipetakan sebagai ruang multidimensi. Singkatnya, clustering berusaha untuk menemukan komponen kelompok secara natural, berdasarkan pada kedekatan data (Irwan B., 2012).

\section{Fuzzy C-Means}

Fuzzy C-Means adalah suatu teknik klasterisasi yang mana keberadaannya tiaptiap titik data dalam suatu klaster ditentukan oleh derajat keanggotaan. Teknik ini pertama kali diperkenalkan oleh Jim Bezdek pada tahun 1981 (Adi S., dkk, 2014).

Konsep dari Fuzzy C-Means pertama kali adalah menentukan pusat klaster, yang akan menandai lokasi ratarata untuk tiap-tiap klaster. Pada kondisi awal, pusat klaster ini masih belum akurat. Tiap-tiap titik data memiliki derajat keanggotaan untuk tiap-tiap klaster. Dengan cara memperbaiki pusat klaster dan derajat keanggotaan tiap-tiap titik data secara berulang, maka akan dapat dilihat bahwa pusat klaster akan bergerak menuju lokasi yang tepat (Adi S., dkk, 2014).

Perulangan ini didasarkan pada minimasi fungsi obyektif yang menggambarkan jarak dari titik data yang diberikan kepusat cluster yang terbobot oleh derajat keanggotaan titik data tersebut. Output dari Fuzzy C-Means merupakan deretan pusat klaster dan beberapa derajat keanggotaan untuk tiaptiap titik data. Informasi ini dapat digunakan untuk membangun suatu fuzzy inference system (Adi S., dkk, 2014).

Langkah-langkah algoritma Fuzzy CMeans (FCM) secara lengkap adalah sebagai berikut (Dimas W., 2013):

1. Menentukan data yang akan di klaster $\mathrm{X}$, berupa matriks berukuran $\mathrm{n} \times \mathrm{m}(\mathrm{n}=$ jumlah sampel data, $m=$ atribut setiap 
data). $X i j=$ data sampel ke-i $(i=1,2$, $\ldots, n)$, atribut ke-j $(j=1,2, \ldots, m)$.

2. Menentukan jumlah klaster (c), pangkat (w), maximum iterasi (Maxlter), error terkecil yang diharapkan $(\zeta)$, fungsi obyektif awal $\left(\mathrm{P}_{0}\right.$ $=0)$, iterasi awal $(t=1)$.

3. Membangkitkan bilangan random $\mu_{\mathrm{ik}}, i$ $=1,2, \ldots, \mathrm{n} ; k=1,2, \ldots, c$; sebagai elemenelemen matriks partisiawal U. Matriks partisi (U) pada pengelompokan fuzzy memenuhi kondisi sebagai berikut :

$$
\mu_{i k} \varepsilon[0,1] ; \quad 1 \leq \mathrm{i} \leq \mathrm{n} ; \quad 1 \leq \mathrm{k}
$$

$\mu_{\mathrm{ik}}$ adalah derajat keanggotaan yang merujuk pada seberapa besar kemungkinan suatu data bias menjadi anggota ke dalam suatu cluster.

4. Menghitung pusat klaster ke-k: $V_{k j}$, dengan $\mathrm{k}=1,2, \ldots, \mathrm{c}$; dan $\mathrm{j}=1,2, \ldots, \mathrm{m}$

$$
V_{k j}=\frac{\sum_{i=1}^{n}\left(\left(\mu_{i k}\right)^{w} X_{i j}\right)}{\sum_{i=1}^{n}\left(\mu_{i k}\right)^{w}}
$$

5. Menghitung fungsi obyektif pada iterasi ke-t, $P_{t}$, (Novi R.,dkk, 2009) :

Fungsi obyektif digunakan sebagai syarat perulangan untuk mendapatkan pusat klaster yang tepat. Sehingga diperoleh kecendrungan data untuk masuk ke klaster mana pada langkah terakhir. Untuk iterasi awal nilai $t=1$.

$$
\left.\left.P_{t}=\sum_{i=1}^{n}\right\rangle_{k=1}^{c}||\right\rangle_{j=1}^{m}\left(X_{i j}-V_{k j}\right)^{2}\left|\left(\mu_{i k}\right)^{w}\right|
$$

6. Menghitung perubahan matriks partisi (Cary L., 2013):

$$
\mu_{i k}=\frac{\left[\sum_{j=1}^{m}\left(X_{i j}-V_{k j}\right)\right]^{\frac{-1}{w-1}}}{\sum_{k=1}^{c}\left|\sum_{j=1}^{m}\left(X_{i j}-V_{i j}\right)^{2}\right|^{\frac{-1}{w-1}}}
$$

7. Mengecek kondisi berhenti :

a. $\left(\left|P_{t}-P_{t-1 \mid}\right|<\xi\right) \operatorname{atau}(t>$ Maxiter) maka berhenti;

b. Jika tidak, iterai dinaikkant $=$ $t+1$,ulangi langkahke4 .

\section{Customer Relationship Management (CRM)}

Perhatian pada Customer Relationship Management (CRM) mulai berkembang pada tahun 1990an (Ling dan Yen, 2001; Xu et al., 2002). Tanpa memperhatikan ukuran suatu organisasi, bisnis tetap didorong untuk menggunakan CRM untuk menciptakan dan mengelola hubungan dengan pelanggan secara lebih efektif. Suatu hubungan yang baik dengan para pelanggan pada akhirnya dapat mengarah kepada loyalitas pelanggan dan retensi, dan juga profitabilitas. Sebagai tambahan, perkembangan internet dan teknologi yang cepat telah sangat meningkatkan peluang bagi pemasaran dan telah mengubah tata kelola hubungan antara perusahaan dengan pelanggannya (Aviliani, 2011).

Customer Relationship Management (CRM) adalah sebuah strategi bisnis untuk memahami, mengantisipasi, dan mengelola kebutuhan pelanggan yang potensial dalam suatu organisasi pada saat sekarang dan yang akan datang. Konsep CRM yang diimplementasikan di berbagai perusahaan lebih didominasi oleh aplikasi-aplikasi pada level operasional, seperti penjualan dan pemasaran. Pemanfaatan perangkat perangkat Analytical CRM seperti business intelligence (BI) belum maksimal dilakukan, akibatnya data transaksi yang bersifat kompleks dan memiliki volume yang besar tidak dapat dijadikan sebagai sumber informasi untuk proses pengambilan keputusan dalam menetapkan strategi CRM selanjutnya (Bayu A. T., 2010).

Peningkatan revenue perusahaan merupakan dampak yang paling bisa dirasakan. Ketika sebuah strategi crossselling dijalankan, fokus utama perusahaan tidak lagi kepada bagaimana mendapatkan pelanggan baru yang potensial (prospecting customer), tetapi bagaimana menjual lebih banyak produk kepada pelanggan yang sudah ada (existing customer). Sebuah 
literatur menyebutkan, bahwa biaya (cost) yang harus dikeluarkan perusahaan untuk mendapatkan pelanggan baru lebih mahal sepuluh kali lipat jika dibandingkan dengan mempertahankan pelanggan yang sudah ada (Bayu A. T., 2010).

Sebagai bagian dari CRM, crossselling harus didahului oleh analisis yang mendalam mengenai data transaksi pelanggan dengan menggunakan konsep Data Mining yang melibatkan proses pengambilan sumber informasi dari sebuah transaksi pelanggan, yang mencakup produk apa yang mereka beli, perilaku pembelian pelanggan, dan lain-lain (Bayu A.T., 2010).

\section{a. Fuzzy Recency Frequency Monetary (RFM)}

Teknik RFM didasarkan pada tiga atribut pelanggan yang sederhana, yaitu Recency of purchase, Frequency of purchase, dan Monetary value of purchase. Tujuan dari RFM Scoring adalah untuk meramalkan perilaku konsumen di masa depan (mengarahkan keputusan segmentasi yang lebih baik). Oleh karena itu, perlu menterjemahkan perilaku konsumen dalam 'angka' sehingga dapat digunakan sepanjang waktu. Terdapat dua cara scoring yang dapat digunakan untuk menilai RFM yaitu Customerquintiles dan Behaviourquintiles (Aviliani, 2011).

Analisa RFM terdiri dari tiga dimensi, yaitu :

1. Recency, yaitu rentang waktu (dalam satuan hari, bulan, tahun) dari transaksi terakhir yang dilakukan oleh konsumen sampai saat ini.

2. Frequency, yaitu jumlah total transaksi atau jumlah rata-rata transaksi dalam satu periode.

3. Monetary, yaitu jumlah rata-rata nilai pembelian konsumen dalam suatu satuan waktu.

Metode mendeskripsikan atribut recency, frequency, dan monetary dengan variabel linguistik. Sebagai contoh, atribut recency dideskripsikan dengan bahasa natural long ago (lama) dan very recent (baru saja). Atribut frequency dideskripsikan dengan bahasa natural rare (jarang) dan frequent (sering). Sedangkan atribut monetary dideskripsikan dengan bahasa natural low value (rendah) dan high value (tinggi).

\section{METODOLOGI PENELITIAN}

Dalam metodologi penelitian ada urutan kerangka kerja yang harus diikuti, urutan kerangka kerja ini merupakan gambaran dari langkah-langkah yang harus dilalui agar penelitian ini berjalan dengan baik. Kerangka kerja yang harus diikuti dapat dilihat pada Gambar 3.1.

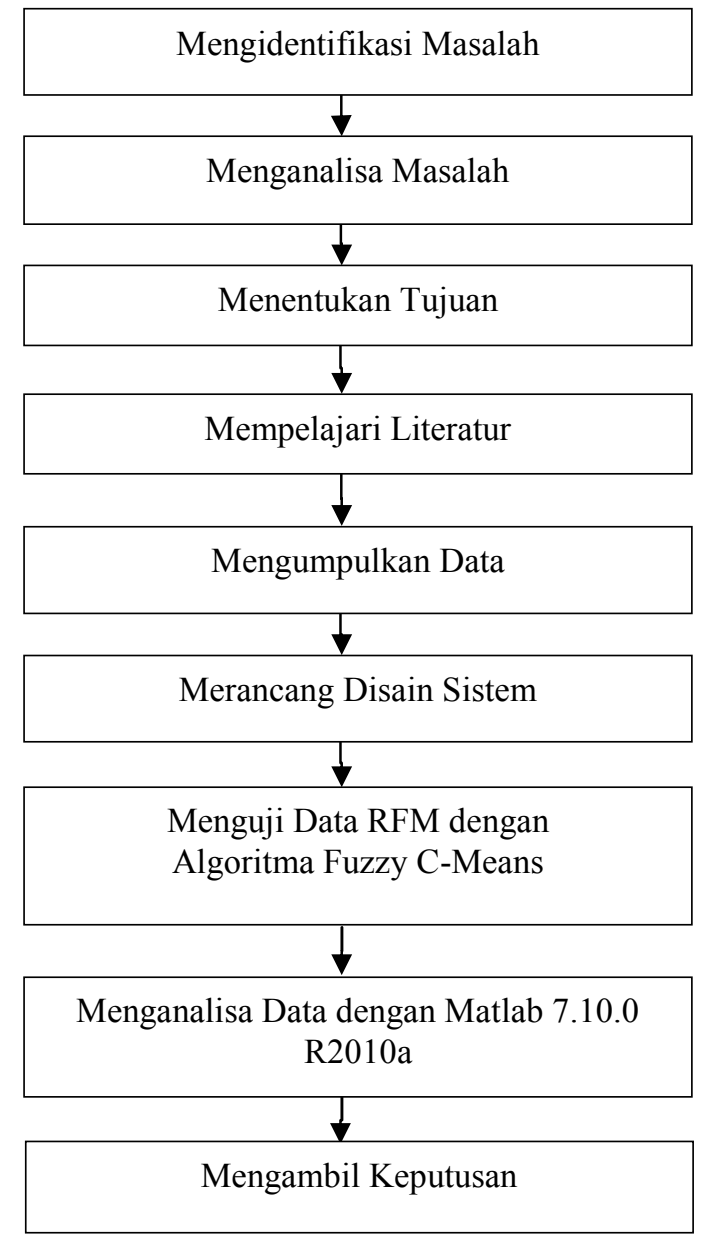

Gambar C.1 Kerangka Kerja

D. ANALISA DAN PERANCANGAN 


\section{Analisa}

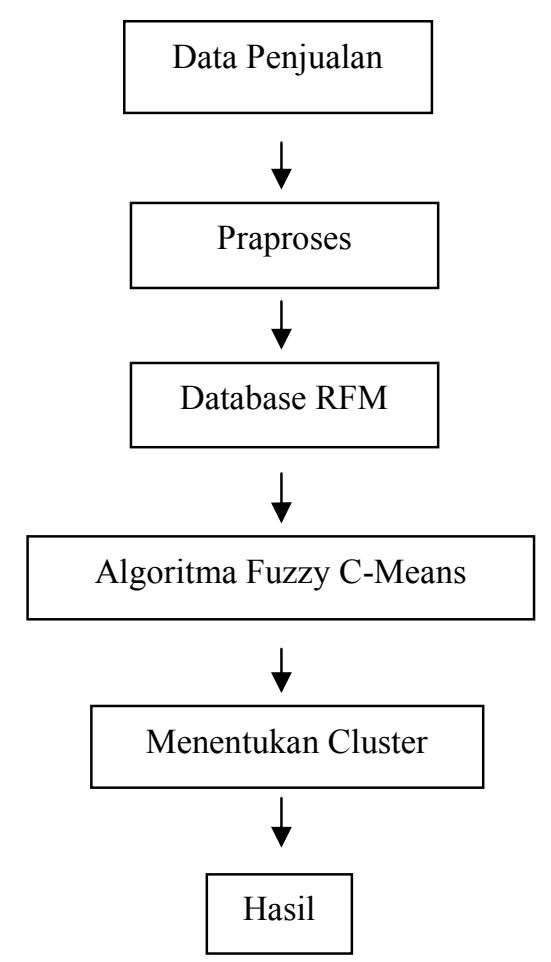

\section{Gambar D.1 Desain Arsitektur Sistem}

\section{Perancangan}

Proses yang dirancang untuk dapat menyelesaikan permasalahan adalah sebagai berikut:

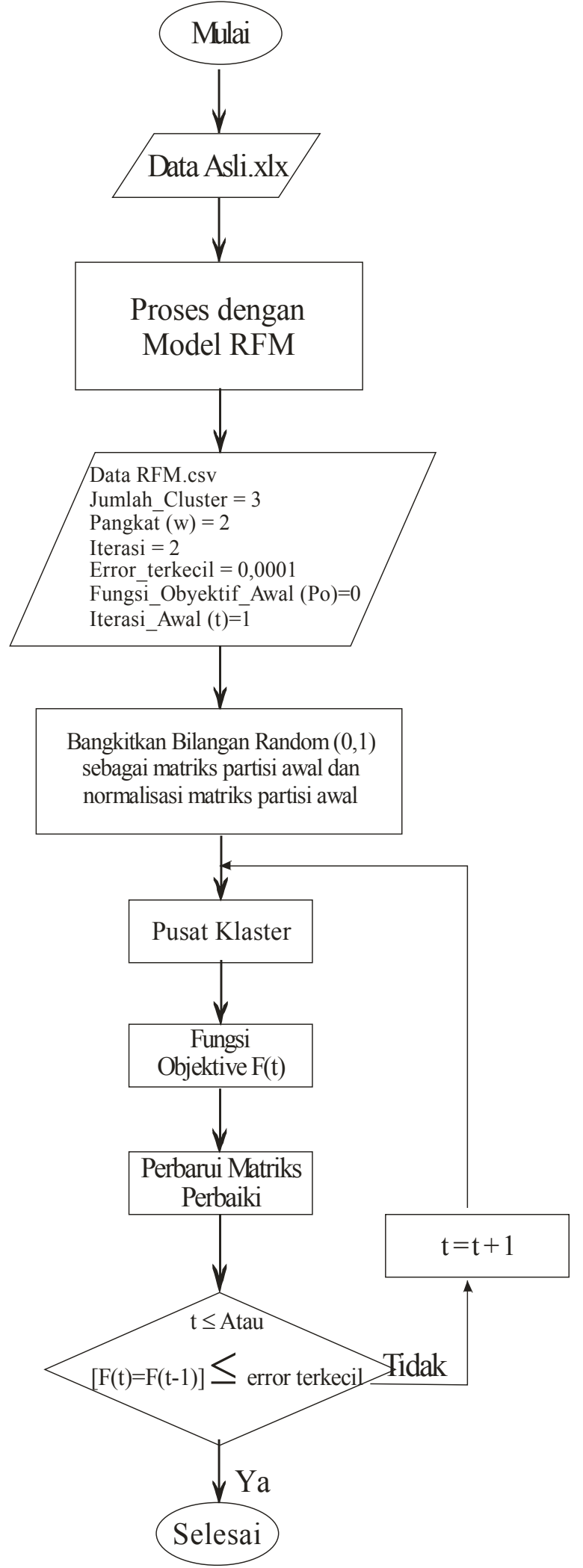

Gambar 4.2 Diagram Alir Fuzzy C-Means 


\section{E. IMPLEMENTASI DAN PENGUJIAN}

Untuk membuktikan kebenaran hasil analisa, diperlukan sebuah proses pengujian untuk menguji kebenaran dari hasil pengolahan data yang dikerjakan secara manual pada BAB IV yang telah dikerjakan sebelumnya. Pada tahapan ini akan membahas implementasi dan proses pengujian menggunakan metode clusteringberdasarkan data yang ada menggunakan Algoritma Fuzzy C-Means dengan Tools Matlab 7.10.0 (R2010a). Adapun yang akan dihasilkan pada BAB $V$ ini yaitu berupa himpunan fuzzy, rule-rule yang telah ditentukan, dan hasil clustering.

\section{Implementasi}

Implementasi merupakan kegiatan yang akan dilakukan setelah perancangan selesai dilakukan. Tahapan implementasi dimaksudkan untuk mengimplementasikan perancangan yang telah dilakukan, sedangkan tahap pengujian adalah tahapan untuk menguji hasil implementasi berdasarkan rancangan yang telah dilakukan. Pada bab ini, akan dibahas tahapan yang dilakukan untuk mengimplementasikan dan menguji penerapan Algoritma Fuzzy C-Means yang dipadukan dengan model fuzzyrecencyfrequencymonetary (RFM).

\section{Pengujian}

Untuk membuktikan kebenaran analisa dari algoritma Fuzzy C-Means secara manual, maka pengujian analisa dilakukan dengan menggunakan fuzzy logic Mamdani. Bahasa pemrograman yang digunakan dalam pengujian ini adalah MATLAB 7.10.0. Adapun tahapan-tahapan yang dilakukan dalam pengujian ini yaitu :

1. Sebelum dilakukan pengujian sistem terhadap data yang ingin diolah, terlebih dahulu harus dipersiapkan data recency, frequency, monetary. Data recency, frequency, monetary diolah menggunakan SoftwareMicrosoftExcel 2007 dalam extention*.csv. Data Recency, Frequency, Monetary, diperlihatkan pada tabel E.1.

Tabel E.1 Tabel Recency, Frequency, Monetary

\begin{tabular}{|c|r|r|r|}
\hline No. & Recency & Frequency & Monetary \\
\hline 1 & 19.286 & 8 & 2231955 \\
\hline 2 & 28.5 & 6 & 2190600 \\
\hline 3 & 95 & 2 & 27897417 \\
\hline 4 & 4.957 & 82 & 5629489 \\
\hline 5 & 28.4 & 7 & 2610000 \\
\hline 6 & 15 & 30 & 3538910 \\
\hline 7 & 11.5 & 32 & 2856924 \\
\hline 8 & 20.222 & 10 & 2272500 \\
\hline 9 & 21.8 & 6 & 2225875 \\
\hline 10 & 18.421 & 21 & 4102893 \\
\hline
\end{tabular}

2. Setelah data RFM diperoleh maka selanjutnya adalah mengolah data menggunakan Matlab.

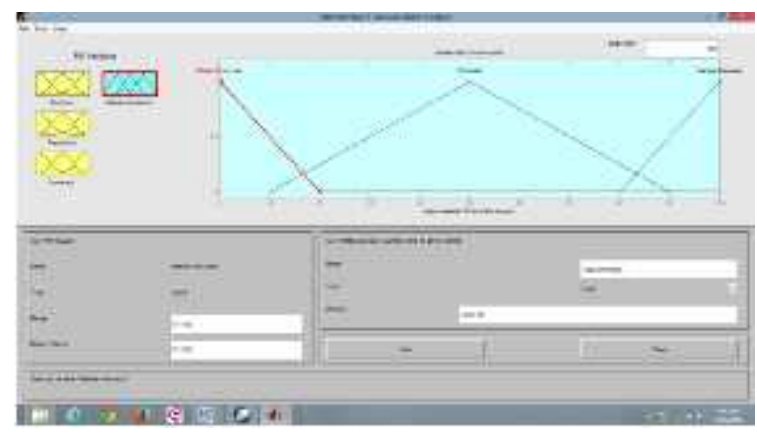

Gambar E.1 Himpunan Fuzzy 


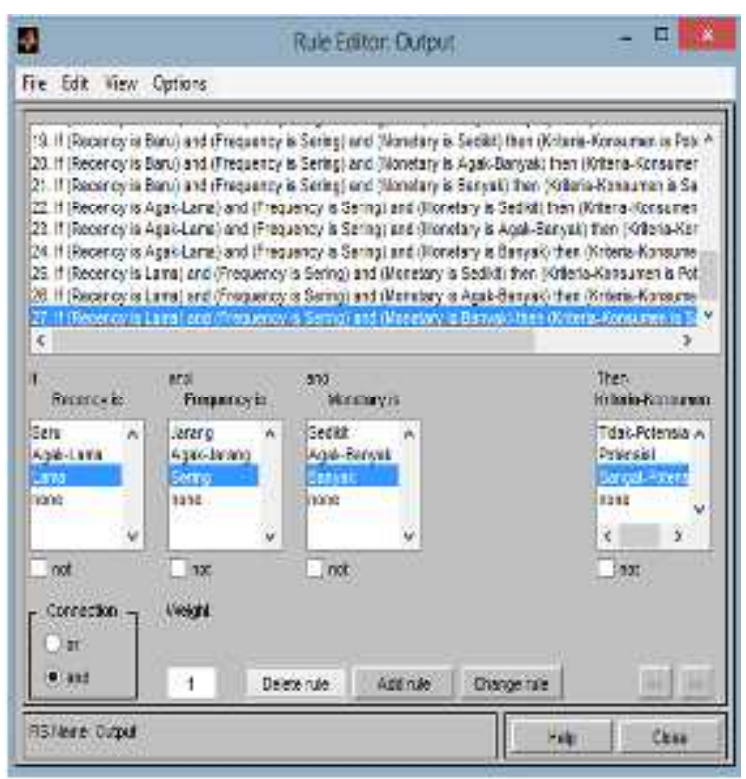

Gambar E.2 Rule-Rule pada Matlab 7.10

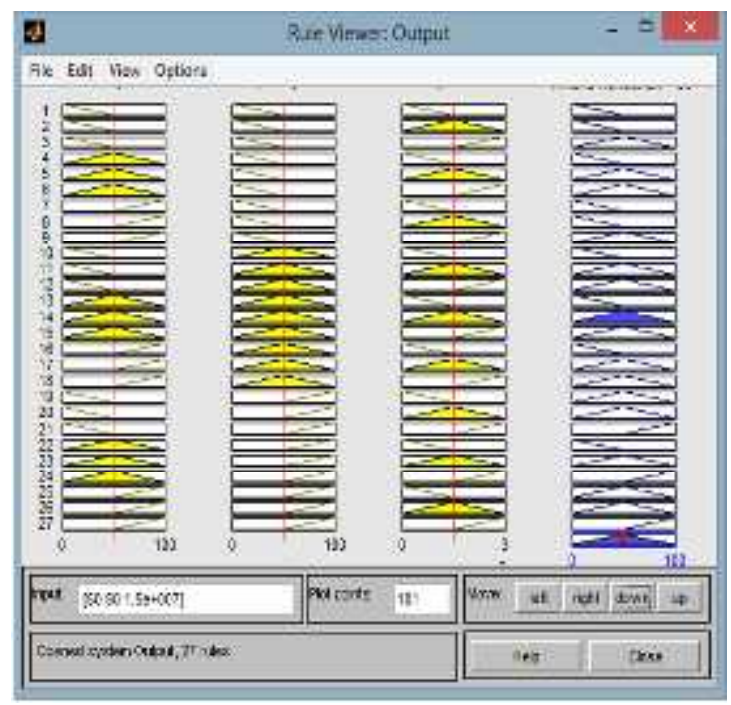

Gambar E.3 Tampilan Rule Viewer

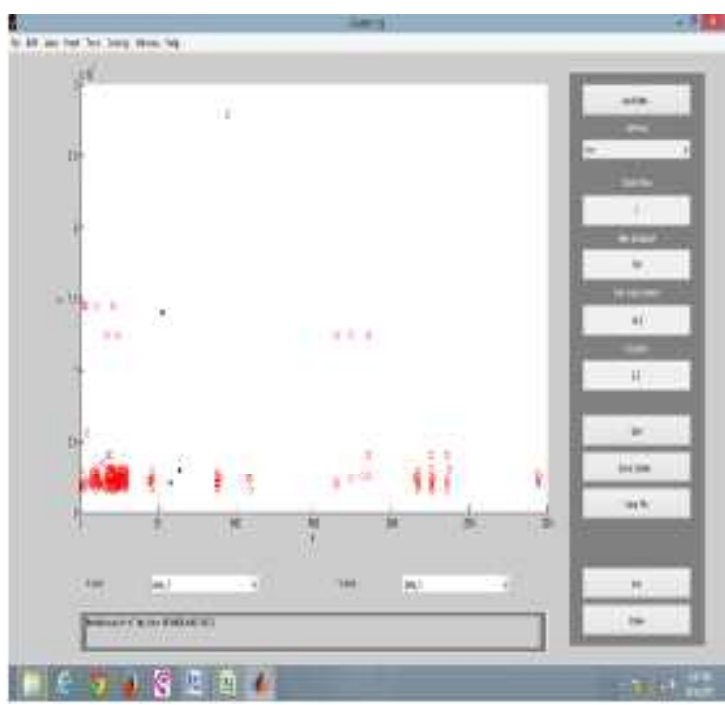

Gambar E.4 Gambar Titik Pusat Cluster 2

\section{F. PENUTUP}

\section{Simpulan}

Berdasarkan hasil penulisan dan pembahasan pada Bab I sampai dengan Bab $V$ yang telah dilakukan, maka dapat diambil kesimpulan yang dapat berguna bagi para pembaca sehingga penulisan tesis ini dapat lebih bermanfaat. Adapun kesimpulan dari penulisan penelitian ini adalah sebagai berikut:

1. Hasil implementasi Metode Clustering dengan Algoritma Fuzzy C-Means untuk menganalisa data konsumen menghasilkan rule-rule yang dijadikan pola keputusan dalam menentukan konsumen potensial pada Toko Sweet Amirah. Adapun seluruh atribut sangat mempengaruhi pada pencapaian hasil "Potensial", di mana jumlah rule yang diperoleh setelah melakukan pengujian sistem dengan menggunakan tools Matlab 7.10.0 (R2010a) adalah sebanyak 27 rule.

2. Hasil implementasi Algoritma Fuzzy CMeans yang dipadukan dengan Model RFM dapat memberikan informasi 
Yohanni Syahra, Yusnidah, Beni Andika, Penerapan Algoritma Fuzzy C-Meanz dipadukan dengan.........

konsumen potensial pada Toko Sweet Amirah.

3. Hasil implementasi Metode Clustering dengan Algoritma Fuzzy C-Means yang dipadukan dengan Model Fuzzy RFM dapat memberikan informasi kosuman potensial untuk Customer Relationship Management.

\section{Saran}

Berikut ini beberapa saran yang penulis berikan dalam rangka pengembangan dan pemanfaatan dari penelitian yang telah dilakukan mengenai implementasi Metode Clustering dengan Algoritma Fuzzy C-Means. Adapun saran dari penulisan penelitian ini adalah sebagai berikut:

1. Untuk penelitian selanjutnya dapat menggunakan metode yang lain dari metode yang diangkat dari penelitian ini sebagai perbandingan sehingga dapat diperoleh metode yang terbaik dalam menentukan konsumen potensial pada perusahaan retail.

2. Penelitian ini mengacu pada atribut yang digunakan untuk konsumen potensial sehingga untuk penelitian selanjutnya dapat dikembangkan lagi untuk atribut yang lain seperti produkproduk yang terlaris dalam satu tahun.

3. Untuk Toko Sweet Amirah, hasil dari penelitian yang telah dilakukan dapat dijadikan pegangan dan acuan yang jelas dalam menentukan konsumen potensial yang dapat diberikan reward setiap tahunnya.

\section{G. DAFTAR PUSTAKA}

Adi Suryaputra P. 2014. "Klasterisasi dan Analisis

Trafik
InternetMenggunakan Fuzzy CMeans dengan Ekstraksi Fitur Data". Jurnal Informatika, Vol. 12, No. 1.

Aviliani. 2011. "Segmentasi Nasabah Tabungan Mikro Berdasarkan Recency, Frequency, dan Monetary : Kasus Bank BRI" ISSN 1410-8623 Finance and Banking Journal, Vol. 13 No. 1.

Bayu Adhi Tama. 2010. "Penetapan Strategi Penjualan Menggunakan Association Rules dalam Konteks CRM". Jurnal Generic, Vol 5 No 1.

Cary Lineker Simbolon. 2013. "Clustering Lulusan Mahasiswa Matematika FMIPA UNTAN Pontianak Menggunakan Algoritma Fuzzy CMeans".Volume 02, No. 1.

Dimas Wahyu Wibowo. 2013. "Perhitungan Jumlah Jenis Kendaraan Menggunakan Metode Fuzzy CMeans dan Segmentasi Deteksi Tepi Canny". Jurnal EECCIS Vol. 7, No. 2.

Hemlata Sahu. 2010. "A Brief Overview on Data Mining Survey". IJCTEE, Volume 1, Issue 3.

Irwan Budiman. 2012. "Data Clustering Menggunakan Metodologi CRISPDM Untuk Pengenalan Pola Proporsi Pelaksanaan Tri Dharma" Semarang.

Mujib Ridwan. 2013."Penerapan Data Mining Untuk Evaluasi Kinerja Akademik Mahasiswa Menggunakan Algoritma NaïveBayesClassifier". Jurnal EECCIS, Vol 7, No. 1.

$\begin{array}{ccc}\text { Novy } & \text { Reandy } & \text { Sasmita. } \\ \text { Perbandingan } & \text { 2009.“ }\end{array}$ 
Yohanni Syahra, Yusnidah, Beni Andika, Penerapan Algoritma Fuzzy C-Meanz dipadukan dengan.........

Means (FCM) dan Fuzzy C-Shell

(FSC) Menggunakan Data Citra

Satelit Quickbird (Studi Kasus

Daerah Peukan Bada, Aceh Besar)". Jurnal Sains, Aceh,.

Sutisno. 2013. “Penerapan Data Mining Pada Penjualan Menggunakan Metode Clustering Study Kasus PT. Indomarco Palembang". Jurnal IImiah Teknik Informatika IImu Komputer, Vol x No.x, 4.

Yohana Nugraheni. 2011. "DataMining Dengan Metode Fuzzy Untuk CustomerRelationshipManagement( CRM) Pada Perusahaan Retail”. Bali. 